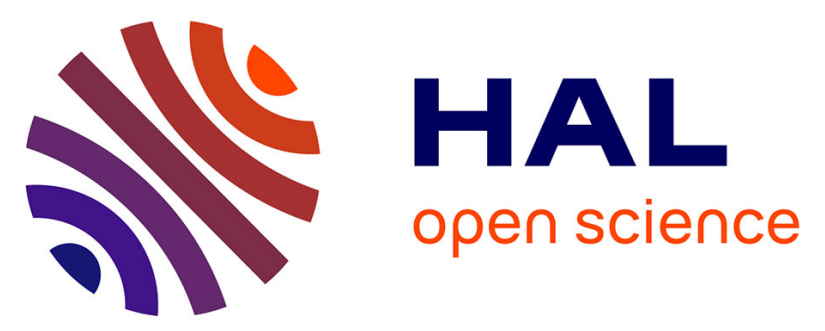

\title{
VIRAL INFECTIONS IN BONE MARROW TRANSPLANTS: IS JC VIRUS INVOLVED?
}

\author{
Monica Mischitelli, Daniela Fioriti, Elena Anzivino, Anna Bellizzi, Valentina \\ Barucca, Renzo Boldorini, Umberto Miglio, Simona Sica, Federica Sorà, Silvia \\ de Matteis, et al.
}

\section{To cite this version:}

Monica Mischitelli, Daniela Fioriti, Elena Anzivino, Anna Bellizzi, Valentina Barucca, et al.. VIRAL INFECTIONS IN BONE MARROW TRANSPLANTS: IS JC VIRUS INVOLVED?. Journal of Medical Virology, 2009, 82 (1), pp.138. 10.1002/jmv.21558 . hal-00541146

\author{
HAL Id: hal-00541146 \\ https://hal.science/hal-00541146
}

Submitted on 30 Nov 2010

HAL is a multi-disciplinary open access archive for the deposit and dissemination of scientific research documents, whether they are published or not. The documents may come from teaching and research institutions in France or abroad, or from public or private research centers.
L'archive ouverte pluridisciplinaire HAL, est destinée au dépôt et à la diffusion de documents scientifiques de niveau recherche, publiés ou non, émanant des établissements d'enseignement et de recherche français ou étrangers, des laboratoires publics ou privés. 
Journal of Medical Virology

WILEY

\section{VIRAL INFECTIONS IN BONE MARROW TRANSPLANTS: IS JC VIRUS INVOLVED?}

\begin{tabular}{|c|c|}
\hline Journal: & Journal of Medical Virology \\
\hline Manuscript ID: & JMV-09-1220.R4 \\
\hline Wiley - Manuscript type: & Research Article \\
\hline $\begin{array}{r}\text { Date Submitted by the } \\
\text { Author: }\end{array}$ & 29-Apr-2009 \\
\hline Complete List of Authors: & $\begin{array}{l}\text { Mischitelli, Monica; "Sapienza" University, Public Health Sciences } \\
\text { Fioriti, Daniela; "Sapienza" University, Public Health Sciences } \\
\text { Anzivino, Elena; "Sapienza" University, Public Health Sciences } \\
\text { Bellizzi, Anna; "Sapienza" University, Public Health Sciences } \\
\text { Barucca, Valentina; "Sapienza" University, Public Health Sciences } \\
\text { Boldorini, Renzo; University Amedeo Avogadro of East Piedmont, } \\
\text { Medical Sciences } \\
\text { Miglio, Umberto; University Amedeo Avogadro of East Piedmont, } \\
\text { Medical Sciences } \\
\text { Sica, Simona; University Â } \square \text { Cattolica del Sacro Cuore, } \\
\text { Haematology } \\
\text { Sorà, Federica; University Â } \square \text { Cattolica del Sacro Cuore, } \\
\text { Haematology } \\
\text { De Matteis, Silvia; University Â } \square \text { Cattolica del Sacro Cuore, } \\
\text { Haematology } \\
\text { Chiarini, Fernanda; "Sapienza" University, Public Health Sciences } \\
\text { Pietropaolo, Valeria; "Sapienza" University, Public Health Sciences }\end{array}$ \\
\hline Keywords: & $\begin{array}{l}\text { JC virus infection, Bone marrow transplants, Haemorrhagic cystitis, } \\
\text { Quantitative PCR, Sequencing analysis }\end{array}$ \\
\hline
\end{tabular}

\section{s scholarONE" \\ Manuscript Central}




\section{VIRAL INFECTION IN BONE MARROW TRANSPLANTS: \\ IS JC VIRUS INVOLVED?}

Running head: JC virus infection in bone marrow transplants

Monica Mischitelli ${ }^{1}$, Daniela Fioriti ${ }^{2}$, Elena Anzivino ${ }^{1}$, Anna Bellizzi ${ }^{1}$, Valentina Barucca ${ }^{1}$, Renzo Boldorini ${ }^{3}$, Umberto Miglio $^{3}$, Simona Sica $^{4}$, Federica Sorà ${ }^{4}$, Silvia De Matteis ${ }^{4}$, Fernanda Chiarini ${ }^{1}$, Valeria Pietropaolo ${ }^{1}$.

${ }^{1}$ Department of Public Health Sciences, "Sapienza" University, Rome, Italy; ${ }^{2}$ Department of Urology, "Sapienza" University, Rome, Italy; ${ }^{3}$ Department of Medical Sciences, Faculty of Medicine, University Amedeo Avogadro of East Piedmont, Novara, Italy; ${ }^{4}$ Department of Haematology, University “Cattolica del Sacro Cuore, Rome, Italy.

\#Corresponding Author:

Valeria Pietropaolo, $\mathrm{PhD}$

"Sapienza” University,

Department of Public Health Sciences,

P.le Aldo Moro, 500185 Rome, Italy.

Phone +390649914439

Fax +39-06-49914626

E-mail: valeria.pietropaolo@uniroma1.it

Keywords: JC virus infection, Bone marrow transplants, Haemorrhagic cystitis; Quantitative PCR; Sequencing analysis. 


\begin{abstract}
Haemorrhagic cystitis is characterized by haematuria due to inflammation of the bladder. In bone marrow transplants, this disease is linked to the infection by human polyomavirus BK, whereas the role of the human polyomavirus JC is unclear. The transcriptional control regions of both viruses contain important cellular transcription factor binding sites that undergo rearrangement process generating suitable variants that could be more active for viral replication and for the onset of haemorrhagic cystitis.

In this study urine obtained from seven patients with bone marrow transplant were examined. Polyomavirus genomes were quantified by PCR and viral loads were compared. The transcriptional regions of both viruses were amplified and sequenced to determine the presence of variants. Subtypes of polyomaviruses were determined by amplification and sequencing of the viral protein 1 region.

The results showed that 4 of 7 patients were positive for BK DNA, 2 of 7 patients had BK and JC DNA and 1 of 7 had JC DNA. Positive samples were amplified and sequenced successively for transcriptional regions. The viral archetype was always found in both viruses. Finally, typing showed that BK virus subtype I infected patients with BK, whereas JC virus genotype IA and genotype 1B were found in patients infected with JC.

The data suggest that new and different approaches are required to improve the morbidity and mortality caused by polyoma-associated haemorrhagic cystitis, since it known that BK virus is involved in the onset of haemorrhagic cystitis, whereas the role of JC virus should be investigated further.
\end{abstract}




\section{INTRODUCTION}

Haemorrhagic cystitis is characterized by painful haematuria due to haemorrhagic inflammation of the bladder mucosa. It is a distinct clinical disease that has been associated with various predisposing factors [DeVries and Freiha, 1990] and it is an important cause of morbidity and occasional mortality in patients undergoing bone marrow transplantation [Sencer et al., 1993]. The clinical features of haemorrhagic cystitis vary from microscopic haematuria to severe haemorrhage in the bladder leading to clot retention and renal failure. Cystitis can be classified into two types: early onset haemorrhagic cystitis, which occurs within 48-72 hours of a conditioning regimen, and a later onset haemorrhagic cystitis, which occurs beyond 72 hours from the preparative regimen. The incidence of haemorrhagic cystitis varies from 7\% to 68\% [Santos et al., 1983; Brugieres et al., 1989; Sencer et al., 1993; Russel et al., 1994; Yang et al., 1994; Bedi et al., 1995; Leung et al., 2001; Xu et al., 2007].

Numerous causes, such as chemical immunosuppression and irradiation, cytopenia and viral infections, can contribute to the onset of haemorrhagic cystitis. Infection or reactivation of the human polyomavirus $\mathrm{BK}$ is common and represents a consistent risk factor for the development of this disease. It has been associated with a later onset haemorrhagic cystitis in patients undergoing allogeneic haematopoietic stem cell transplantation [Reploeg et al., 2001; Leung et al., 2005; Giraud et al., 2006; Giraud et al., 2008]. On the other hand, the role of the human polyomavirus JC is still poorly understood.

The two human polyomaviruses BK and JC belongs to the Polyomaviridae, a family of small nonenveloped icosahedral DNA viruses, which infect human population worldwide [Imperiale, 2001].

The BK viral genome can be divided into an early region (regulatory proteins), a late region (viral capsid proteins and the agnoprotein) and a transcriptional control region, which contains the origin of replication and sequences for transcriptional cell factors involved in early and late viral transcription [Moens and Van Ghelue, 2005]. These binding sites undergo deletion and 
enhancement process that could generate variants that could offer advantages to the virus in its host [Sharma et al., 2007].

Four antigenic subtypes of BK virus (I-IV) have been characterised by genomic subtyping and serological reactivity [Jin et al., 1995]. The association of a particular BK virus subtype with clinical features is controversial, although some investigators demonstrated that BK virus subtype I was the predominant in urine samples taken from bone marrow transplants affected by haemorrhagic cystitis [Bogdanovic et al., 1998; Fioriti et al., 2005].

Like BK virus, the JC viral genome is divided into three regions: the early, the late and the transcriptional control region which includes the origin of replication and contains binding sites for transcriptional cell factors involved in viral early and late transcription [Frisque et al., 1984; Kim et al., 2001]. Like BK virus, deletion and enhancement process could give rise to more active variants with altered tissue tropism and pathogenic capability [Vaz et al., 2000; Pietropaolo et al., 2003; Mischitelli et al., 2005]. The analysis of the viral protein 1 gene allowed to distinguish 8 major genotypes and numerous subtypes of JC virus [Kmieciak et al., 2008]. Types I and IV predominate in Europe and in the USA [Jobes et al., 1998; Stoner et al., 2000; Agostini et al., 2001; Pagani et al., 2003].

Primary polyomavirus infection is usually asymptomatic and is acquired during childhood probably via the upper respiratory tract and other ways [Brown et al., 1984; Sundsfjord et al., 1994; Pietropaolo et al., 1998; Zambrano et al., 2002; Ahsan and Shah, 2006; Knowles, 2006]. Following primary infection, these viruses disseminate and establish lifelong persistence especially in the kidney [Imperiale, 2000; Rabenau et al., 2002]. Reactivation may occur in conditions of immunosuppression such as following bone marrow and kidney transplantations [Drachenberg et al., 2007; Boldorini et al., 2008; Dropulic and Jones, 2008]. JC virus is the etiologic agent of a rare neurodegenerative disease named Progressive Multifocal Leukoencephalopathy, whereas BK virus causes nephropathy in kidney transplant patients and it is associated with haemorrhagic cystitis in 
allogeneic bone marrow transplants [Khalili et al., 2006; Mischitelli et al., 2007; Giraud et al., 2008].

About 50-100\% patients with a bone marrow transplant develops BK viruria, nevertheless only 5$40 \%$ progress to haemorrhagic cystitis indicating that a specific subtype, genome mutations and graft versus host disease may contribute to its development [Bogdanovic et al., 1996; Azzi et al., 1999; Leung et al., 2001; Carr et al., 2006; Ikegaya et al., 2006; Giraud et al., 2008]. Nevertheless, very few studies have been carried out linking haemorrhagic cystitis with polyomavirus infection and some studies pointed to a significant correlation between the pathogenesis and shedding of polyomavirus in urine, whereas data from other studies showed no such relationship [Rabenau et al., 2002; Bogdanovic et al., 2004; Erard et al., 2005; Fioriti et al., 2005; Giraud et al., 2006].

In order to assess better the association of $\mathrm{BK}$ and/or JC viruses infection with the onset of haemorrhagic cystitis or progression, urine taken from patients with bone marrow transplants and immunocompetent individuals was analyzed. BK virus and JC virus genomes were quantified and viral loads were compared to determine whether high peak urine viral loads were linked to the onset of haemorrhagic cystitis and with variation of immunosuppressive therapy. In addition, BK virus and JC virus transcriptional control regions were amplified and sequenced to determine whether if mutations in transcription factor binding sites were associated with a more aggressive pathology. Finally, the BK and JC viruses were subtyped to determine whether a particular subtype was circulating most commonly in bone marrow transplants. 


\section{MATERIALS AND METHODS}

\section{Patients and clinical specimens}

This study was based on seven Caucasian patients (two males and five females) who underwent allogeneic bone marrow transplantation and developed post-transplant haemorrhagic cystitis. The average age of the patients was 35 for females (30-45) and 32 for males (24-39). They were admitted to "Policlinico Gemelli" Hospital of Rome with a different diagnosis of haematopoietic malignancies, none had a history of urinary tract infection, coagulopathy, pelvic irradiation or evidence of microscopic haematuria prior to bone marrow transplantation. All patients received allogeneic bone marrow transplants. One of these patients received a bone marrow transplant from a relative and six from matched unrelated donors. The seven patients developed haemorrhagic cystitis at an average of 33 days after bone marrow transplantation. The clinical data of the patients are shown in Table 1. Seven healthy individuals were recruited as controls.

Specimens were collected when haematuria was evident or when the symptoms were of haemorrhagic cystitis. Two patients were also infected with BK virus and JC virus and had recidivant haemorrhagic cystitis. Serial urine specimens were collected from these two patients from the onset of the symptoms to determine whether high peak urine viral loads were associated with haemorrhagic cystitis episodes and with variation of immunosuppressive therapy. Investigations were made on fresh uncentrifuged urine.

Informed consent was obtained from each patient and each volunteer and the study design was approved by the medical ethics committee of the "Policlinico Gemelli" Hospital of Rome.

\section{Diagnosis and treatment.}

Haemorrhagic cystitis was diagnosed by urine culture and PCR to distinguish bacterial disease from viral etiology. The treatment is shown in Table 2. 


\section{DNA extraction}

One millilitre of urine was incubated in lysis buffer and proteinase $\mathrm{K}(200 \mathrm{mg} / \mathrm{ml})$. DNA extraction was performed by the DNeasy® Tissue Kit (QIAGEN S.p.A., Milan, Italy), according to the manufacturer's instructions.

\section{PCR analysis}

Urine was examined using quantitative assays for quantitation of BK virus and JC virus DNA. The specimens with BK and/or JC DNA were then analyzed using qualitative assays for the detection of viral transcriptional control regions and for virus typing.

\section{$B K$ virus quantitative PCR}

The assay was performed using 7300 Real Time PCR System (AB Applied Biosystems, 850 Lincoln Centre DriveFoster City, CA 94404 USA). PCR amplifications were run in a reaction volume of $20 \mu \mathrm{l}$ (optimized mix including forward and reverse primers and hydrolysis probes) containing $5 \mu \mathrm{l}$ of DNA sample. $50 \mathrm{ng} / \mu \mathrm{L}$ of total purified DNA was used.

Thermal cycling was initiated with a first denaturation step of $10 \mathrm{~min}$ at $95^{\circ} \mathrm{C}$, followed by 45 cycles of $95^{\circ} \mathrm{C}$ for $15 \mathrm{~s}, 60^{\circ} \mathrm{C}$ for $1 \mathrm{~min}, 72^{\circ} \mathrm{C}$ for $1 \mathrm{~min}$, at the end of which, fluorescence was read. Amplification data were analyzed with software provided by the manufacturer. Standard curves for the quantitation of the viral genome were constructed using serial dilutions of a plasmid containing the target sequences (Large $\mathrm{T}$ Antigen). Concentrations of the plasmid ranged from $10^{2}$ to $10^{5}$ copies of target plasmid. All samples were tested in triplicate and the number of viral copies in each sample was calculated from the standard curve. The results were expressed as copies of viral DNA per milliliter $(\mathrm{c} / \mathrm{ml})$ of sample. Standard precautions to prevent contamination were followed. In each run non-template control lanes were included. The assay can to detect about 10 molecules of target sequences in $5 \mu \mathrm{l}$ of DNA. 


\section{$J C$ virus quantitative $P C R$}

The assay was performed using 7300 Real Time PCR System (AB Applied Biosystems, 850 Lincoln Centre DriveFoster City, CA 94404 USA). PCR amplifications were run in a reaction volume of $40 \mu \mathrm{l}$ containing $10 \mu \mathrm{l}$ of the DNA sample, reaction mix for quantitative amplification, forward and reverse primers and finally SYBR GREEN I probes. $50 \mathrm{ng} / \mu \mathrm{L}$ of total purified DNA was used.

Thermal cycling was initiated with a first denaturation step of 2 min at $94^{\circ} \mathrm{C}$, followed by 40 cycles of $94^{\circ} \mathrm{C}$ for $30 \mathrm{~s}, 60^{\circ} \mathrm{C}$ for $30 \mathrm{~s}, 72^{\circ} \mathrm{C}$ for $30 \mathrm{~s}, 77^{\circ} \mathrm{C}$ for $15 \mathrm{~s}$ at the end of which, fluorescence was read. Dissociation stage was characterized by a temperature curve with an initial step at $65^{\circ} \mathrm{C}$ and a final step at $95^{\circ} \mathrm{C}$. The temperature increment was $0.3^{\circ} \mathrm{C}$ every $10 \mathrm{~s}$. The amplification data were analyzed with a specific software provided by the manufacturer. Standard curves for viral genome quantification were constructed using serial dilutions of a plasmid containing target sequences (Viral Capsid Protein 2). The plasmid concentrations ranged from $10^{2}$ to $10^{5}$ plasmid copies of the target. All samples were tested in triplicate and the number of viral copies in each sample was calculated from the standard curve. PCR specificity was guaranteed by a dissociation stage characterized by curves with melting point of $79^{\circ} \mathrm{C} \pm 1^{\circ} \mathrm{C}$, corresponding to a $132 \mathrm{bp}$ fragment. These data were expressed as $\mathrm{c} / \mathrm{ml}$ of sample. Standard precautions to prevent contamination were followed. In each run non-template control lanes were included. The assay allows to detect about 20 molecules of target sequences in $10 \mu \mathrm{l}$ of DNA.

\section{PCR for transcriptional control region of BK virus}

Samples positive for BK virus genome underwent further amplification for detection of the transcriptional region using a nested PCR with BKTT1 and BKTT2 as outer primers and BRP1 and BRP2 (356 bp) as inner primers. The amplification was performed in a reaction volume of $25 \mu 1$, containing 10 pmol of each primer, $0.2 \mathrm{mM}$ dNTPs, $1.5 \mathrm{mM} \mathrm{MgCl}$, and 2U BioTaq DNA polymerase with an appropriate reaction buffer (Tris- $\mathrm{HCl} 100 \mathrm{mM}, \mathrm{pH} 8.3, \mathrm{KCl} 500 \mathrm{mM}$ ). In the 


\section{PCR for transcriptional control region of JC virus}

Samples positive for JC virus genome underwent further amplification for detection of the transcriptional region using a nested PCR with JRE1 and LP2 as outer primers and RFOR and RREV (358 bp) as inner primers. The amplification was performed in a reaction volume of $45 \mu 1$, containing 10 pmol of each primer, $0.2 \mathrm{mM}$ dNTPs, $1.5 \mathrm{mM} \mathrm{MgCl}$, and 2U BioTaq DNA polymerase with an appropriate reaction buffer (Tris- $\mathrm{HCl} 100 \mathrm{mM}, \mathrm{pH} 8.3, \mathrm{KCl} 500 \mathrm{mM}$ ). $5 \mu \mathrm{l}$ of DNA was added to the PCR mixture at the first step, whereas $2.5 \mu 1$ of template was added in the second step of PCR. PCR was run in GeneAmp PCR System 9600 (Perkin-Elmer Cetus, Emeryville, CA). $50 \mathrm{ng} / \mu \mathrm{L}$ of total purified DNA was used. The samples were amplified by denaturation at $95^{\circ} \mathrm{C}$ for $5 \mathrm{~min}$, followed by 35 cycles at $95^{\circ} \mathrm{C}$ for $40 \mathrm{~s}$, annealing for $40 \mathrm{~s}$ at $61^{\circ} \mathrm{C}$ in the first step and $58^{\circ} \mathrm{C}$ in the second step, and extension at $72^{\circ} \mathrm{C}$ for $40 \mathrm{~s}$. The cycles were terminated with a final extension at $72^{\circ} \mathrm{C}$ for $5 \mathrm{~min}$. All assays included positive (purified viral DNA) and negative (all the PCR components except the template) controls to exclude false-positive and false-negative results. PCR products were analyzed by means of $2 \%$ agarose gel electrophoresis and visualized using ethidium bromide staining [Boldorini et al., 2008]. 


\section{Sequencing of transcriptional control regions of BK and JC viruses}

PCR products corresponding to transcriptional control regions of BK and JC viruses were purified and sequenced. Briefly, amplicons were purified prior sequencing to remove the excess of primers with QIAquick PCR purification kit, according to QIAGEN protocol. DNA sequencing was performed by automatic DNA sequencer (Applied Biosystem, 850 Lincoln Centre DriveFoster City, CA 94404 USA, mod. 370 A), according to manufacturer's specifications (Amplicycle Kit, Applied Biosystem, 850 Lincoln Centre DriveFoster City, CA 94404 USA). Sequences were organised and analyzed using homology analysis, multiple alignments and the Genetic Computer Group sequence analysis software package. In particular the obtained sequences were compared with BK virus archetype (Genbank Accession Number V01108) and JC virus archetype (Genbank Accession Number J02226).

\section{PCR for viral capsid protein 1 of BK and JC viruses}

In order to amplify genome region corresponding to viral capside protein 1 of BK virus, a nested PCR was performed using VP1-7 and VP1-2R as outer primers, and 327-1 and 327-2 as inner primers (327 bp), reported by Jin et al., 1993. The amplification was performed in a reaction volume of $20 \mu \mathrm{L}$ containing $10 \mathrm{pmol} / \mu \mathrm{L}$ of each primer, $0.2 \mathrm{mM}$ dNTPs , $1.5 \mathrm{mM} \mathrm{MgCl} 2,2 \mathrm{U}$ BioTaq DNA polymerase and 10x Bioline NH4 buffer. In the first step, $5 \mu \mathrm{L}$ of DNA was added to the PCR mixture and, in the second step, $2.5 \mu \mathrm{L}$ of template. The nested PCR was performed using an Eppendorf Mastercycler gradient PCR System. $50 \mathrm{ng} / \mu \mathrm{L}$ of DNA was used. The samples were amplified by means of denaturation at $95^{\circ} \mathrm{C}$ for $5 \mathrm{~min}$, followed by 35 cycles (30 cycles for the inner PCR), at $95^{\circ} \mathrm{C}$ for $40 \mathrm{~s}$, annealing at $55^{\circ} \mathrm{C}$ for $40 \mathrm{~s}$ and extension at $72^{\circ} \mathrm{C}$ for $40 \mathrm{~s}$. The cycles were terminated with a final extension at $72^{\circ} \mathrm{C}$ for $5 \mathrm{~min}$.

Single step PCR was used to amplify the genome region corresponding to viral capside protein 1 of JC virus, using JLP15 and JLP16 primers (215 bp) reported by Pagani et al. 2003. The amplification 
Direct DNA sequencing for viral genotyping.

PCR products corresponding to the viral capsid protein 1 region of both viruses were separated by electrophoresis on 3\% agarose gel. The fragment corresponding to each sample (327 bp for BK virus and 215 bp for JC virus) was excised, extracted and purified using a commercial kit (PCR clean-up gel extraction, NucleoSpin Macherey-Nagel, 52355 Düren, Germany).

A cycle sequencing PCR reaction was performed as previously described [Boldorini et al., 2008]. In order to avoid Taq polymerase mistakes [Jin et al., 1993], the sequence was analyzed twice for each sample. The sequences were read manually, compared with the prototypes (Dunlop strain for BK virus and Mad-1 strain for JC virus) and classified into known genotypes [Jin et al., 1993; Agostini et al., 2001]. The known genotypes are distinguished on the basis of specific polymorphisms within the portion of the viral protein 1 region spanning nucleotides 1744-1812 (BK virus) and nucleotides 1735-1902 (JC virus). The presence of single mutations was also noted. 


\section{RESULTS}

In this study, urine from seven Caucasian patients who developed post-transplant haemorrhagic cystitis was analyzed.

Quantitative results showed that 4 of 7 patients had BK DNA, 2 of 7 patients had BK and JC DNA, whereas only one patient had JC DNA. Patient no.1 developed haemorrhagic cystitis 60 days after transplantation when, BK virus quantitative assay showed $65 \times 10^{8} \mathrm{DNA} \mathrm{c} / \mathrm{ml}$, whereas JC virus quantitative PCR revealed that the specimen was suitable for analysis, but it did not have viral DNA (Tab.3). In patient no.2, $15 \times 10^{7} \mathrm{c} / \mathrm{ml}$ of BK virus DNA was found, whereas the urine did not have JC viral DNA (Tab.3). The BK virus quantitative assay performed on the urine of patient no.3 revealed that there were $33 \times 10^{7} \mathrm{c} / \mathrm{ml}$ of viral DNA, but in the some specimen JC viral DNA was not found (Tab.3). In urine obtained from patient no.4, the quantitative PCR revealed the presence of $14 \times 10^{7} \mathrm{c} / \mathrm{ml}$ of BK virus DNA whereas JC DNA was not found (Tab.3).

In patient no.5, JC DNA quantification showed a number of viral DNA copies of $63 \times 10^{7} \mathrm{c} / \mathrm{ml}$, whereas BK DNA was not found (Tab.3). The quantitative assays for patients no.6 and no.7 showed that these subjects were co-infected with JC and BK viral DNA. For patient no.6, the BK virus DNA copies were $12 \times 10^{8} \mathrm{c} / \mathrm{ml}$ in the urine collected on $12-22-2006$, whereas JC virus DNA copies were $9 \times 10^{5} \mathrm{c} / \mathrm{ml}$. During the serial collection of specimens, corresponding to a recidivant haemorrhagic cystitis, the BK virus DNA average was $52 \times 10^{7} \mathrm{c} / \mathrm{ml}$, whereas the JC virus DNA average was $6 \times 10^{6} \mathrm{c} / \mathrm{ml}$. In the sample analyzed during the follow-up after remission (07-24-2007), $9 \times 10^{5} \mathrm{c} / \mathrm{ml}$ of BK virus DNA were detected, whereas the JC virus DNA copies were $10^{4} \mathrm{c} / \mathrm{ml}$. For patient no.7, in the urine collected on 03-07-2007, the assays quantified $5 \times 10^{3} \mathrm{c} / \mathrm{ml}$ of BK virus DNA and $4 \times 10^{6} \mathrm{c} / \mathrm{ml}$ of JC virus DNA. In the specimens collected during recidive, a BK virus DNA average of $6 \times 10^{4} \mathrm{c} / \mathrm{ml}$ was detected, whereas the JC virus DNA average was $3 \times 10^{6} \mathrm{c} / \mathrm{ml}$. In the urine collected on 09-03-2007 (follow-up after remission), the number of copies of BK and JC viruses DNA decreased to $10^{3} \mathrm{c} / \mathrm{ml}$ for BK virus and $10^{4} \mathrm{c} / \mathrm{ml}$ for JC virus (Table 3). No control subject was found positive (data not shown). 
Samples with viral DNA were amplified and sequenced successively for viral transcriptional control regions. Homology analysis, multiple alignments and the Genetic Computer Group sequence analysis always revealed the presence of the BK and JC viral archetypes in all sequences obtained from the specimens of all patients.

The antigenic subtyping of BK and JC viruses revealed that BK virus type I, corresponding to the MM strain, was found in patients infected with BK including those co-infected. JC virus genotype IA was found in all samples obtained from co-infected patients, whereas in the patient infected only with JC virus, genotype IB was detected (Tab.3). 


\section{DISCUSSION}

Haemorrhagic cystitis is a distinct clinical disorder of multiple etiologies. It is characterized by painful haematuria due to haemorrhagic inflammation of the bladder mucosa [Leung et al., 2005]. The disease that occurs before the graft is mostly transient and self-limiting, whereas after the graft, it is severe and sometimes life threatening [Leung et al., 2005].

About $50 \%$ of bone marrow transplants show BK viruria within 2 months of transplantation; it is similar in allogeneic (range 46-53\%) and autologous (range 39-54\%) transplants [Bedi et al., 1995; Azzi et al., 1999; Dropulic and Jones, 2008]. Although the association of BK virus infection with haemorrhagic cystitis in bone marrow recipients was first demonstrated two decades ago, the role of JC virus remains obscure. However, it is known that bone marrow recipients are susceptible to the infection. Boubenider et al. [1999] demonstrated that BK and JC viruses reactivate in 55\% and $6.7 \%$ of bone marrow patients, respectively. BK virus infection or reactivation alone is not sufficient to cause the disease. Nevertheless, the transcriptional control region rearrangements could strengthen the virus tropism and generate more suitable variants that could be more active for viral replication and for the onset or development of haemorrhagic cystitis. A particular BK virus subtype in patients with a bone marrow transplant, could be involved in the onset of haemorrhagic cystitis.

JC viral infection occurs in $<10 \%$ of patients with bone marrow transplant in whom progressive multifocal leukoencephalopathy is a rare complication [Przepiorka et al., 1997; Yasuda et al., 2008]. Like BK virus, JC transcriptional control region variants could alter viral tissue tropism and increase pathogenic capability, even if the genomic structures isolated from urine samples are highly conserved in healthy and immunocompromised individuals and they always appear very similar to that of the archetype [Vaz et al., 2000; Pietropaolo et al., 2003]. Finally it is suggested that different genotypes of JC virus would act differently in immunocompromised individuals as in the case of progressive multifocal leukoencephalopathy [Ferrante et al., 2003]. 
Given this, urine specimens obtained from bone marrow transplanted and immunocompetent individuals were analyzed. BK virus and JC virus genomes were quantified and viral loads were compared to understand if high urine viral loads were correlated to haemorrhagic cystitis episodes. In addition $\mathrm{BK}$ virus and $\mathrm{JC}$ virus transcriptional control regions were amplified and sequenced to investigate if mutations in transcription factor binding sites were associated with a more aggressive pathology. Finally, the BK and JC subtypes were determined to establish whether a particular subtype circulated more commonly in patients with bone marrow transplant.

Quantitative assays showed that four of seven patients were positive for BKV DNA, 2 of 7 patients were BK and JC co-infected, whereas only one patient was positive for JC virus DNA. In particular, it was observed that a high viral load in urine was related to haemorrhagic cystitis episodes in all patients. Interestingly, in serial urine specimens collected from co-infected patients, it was found that when BK virus replication increased, the JC virus replication decreased. Conversely, when the number of copies of JC DNA increased, BK viral DNA decreased. This suggests that both Polyomaviruses may contribute to the pathogenesis or development of haemorrhagic cystitis. It may be that JC virus involvement in transplant diseases is underestimated since the detection of this virus is not required in the diagnostic approach.

The sequencing of the transcriptional control regions of both viruses, revealed that no particular mutations or structures could be associated with a more strong viral replication and disease onset or recidive. Probably, in the genitourinary tract, viral replication did not require specific transcriptional cell factors, so the host proteins may be sufficient to allow virus replication. Therefore, as demonstrated by Gosert et colleagues, the study of functional proteins in permissive cells could help to understand the possible associations between virus replication and the specific subset of transacting factors [Gosert et al., 2008].

According to the literature, BK virus typing showed that subtype I is found most commonly in infected individuals [Zheng et al., 2007; Krumbholz et al., 2008]. This study confirmed previous results that demonstrated how subtype I was predominant in urine samples obtained from patients 
with bone marrow transplants and haemorrhagic cystitis [Fioriti et al., 2005]. The epidemiology of BK virus shows that genotype I is the most common BK virus circulating in Europe and the genome detected most frequently in the Italian population [Stoner et al., 2000; Agostini et al., 2001; Pagani et al., 2003; Rossi et al., 2007]. In these seven patients, the JC genotype IA was detected in coinfected individuals, whereas in patient n.5 the genotype IB was found. Although there are few patients, it may be that this diversity could be used as a tool to outline the origin of infection and the selection of a particular JC genotype in patients co-infected with BK virus.

However, since haemorrhagic cystitis pathology is complex, it is essential to consider many cofactors in its development, such as the conditioning regimen, gender, the donor source and the histocompatibility between recipient and donor patients. Regarding polyomavirus infection, it is important to evaluate the dynamics of the infection, the timing and the frequency of monitoring and how BK and JC viruses are implicated in renal disease in patients with bone marrow transplant. Additional work is required to understand whether the JC virus acts only as a cofactor or it plays a role in the onset or development of haemorrhagic cystitis.

Acknowledgments: This work was partially supported by Italian MIUR grants. 


\title{
REFERENCES
}

Agostini HT, Deckhut A, Jobes DV, Girones R, Schlunck G, Prost MG, Frias C, Pérez-Trallero E, Ryschkewitsch CF, Stoner GL. 2001. Genotypes of JC virus in East, Central and Southwest Europe. J Gen Virol 2: 1221-1231.

Agostini HT, Jobes DV, Stoner GL. 2001. Molecular evolution and epidemiology of JC virus. In: Khalili K, Stoner G.L, editors. Human Polyomaviruses: molecular and clinical perspectives. New York: Wiley-Liss, A John Wiley \& sons, Inc. p 491-526.

Ahsan N, Shah KV. 2006. Polyomaviruses and human diseases. Adv Exp Med Biol 577: 1-18.

\author{
Azzi A, Cesaro S, Laszlo D, Zakrzewska K, Ciappi S, De Santis R, Fanci R, Pesavento G, Calore E, \\ Bosi A. 1999. Human polyomavirus BK (BKV) load and haemorrhagic cystitis in bone marrow \\ transplantation patients. J Clin Virol 14: 79-86.
}

\begin{abstract}
Bedi A, Miller CB, Hanson JL, Goodman S, Ambinder RF, Charache P, Arthur RR, Jones RJ. 1995. Association of BK virus with failure of prophylaxis against haemorrhagic cystitis following bone marrow transplantation. J Clin Oncol 13: 1103-1109.
\end{abstract}
Bogdanovic G, Ljungman P, Wang F, Dalianis T. 1996. Presence of human polyomavirus DNA in the peripheral circulation of bone marrow transplant patients with and without haemorrhagic cystitis. Bone Marrow Transplant 17: 573-576.

Bogdanovic G, Priftakis P, Giraud G, Kuzniar M, Ferraldeschi R, Kokhaei P, Mellstedt H, Remberger M, Ljungman P, Winiarski J, Dalianis T. 2004. Association between a high BK virus 
load in urine samples of patients with graft-versus host disease and development of haemorrhagic cystitis after hematopoietic stem cell transplantation. J Clin Microbiol 42: 5394-5396.

Bogdanovic G, Priftakis P, Taemmeraes B, Gustafsson A, Flaegstad T, Winiarski J, Dalianis T. 1998. Primary BK virus (BKV) infection due to possible BKV transmission during bone marrow transplantation is not the major cause of haemorrhagic cystitis in transplanted children. Pediatr Transplant 2: 288-293.

Boldorini R, Allegrini S, Miglio U, Paganotti A, Veggiani C. 2008. Detection, distribution and pathological significance of BK virus strains isolated from kidney transplant patients with and without polyomavirus-associated nephropathy. Arch Pathol Lab Med in press.

Boldorini R, Veggiani C, Amoruso E, Allegrini S, Miglio U, Paganotti A, Ribaldone R, Monga G. 2008. Latent human polyomavirus infection in pregnancy: investigation of possible transplacental transmission. Pathology 40: 72-77.

Boubenider S, Hiesse C, Marchand S, Hafi A, Kriaa F, Charpentier B. 1999. Post-transplantation polyomavirus infections. J Nephrol 12: 24-29.

Brown DW, Gardner SD, Gibson PE, Field AM. 1984. BK virus specific IgM response in cord sera, young children and healthy adults detected by RIA. Arch Virol 82: 149-160.

Brugieres L, Hartmann O, Travagli JP, Benhamou E, Pico JL, Valteau D, Kalifa C, Patte C, Flamant F, Lemerle J. 1989. Haemorrhagic cystitis following high-dose chemotherapy and bone marrow transplantation in children with malignancies: incidence, clinical course, and outcome. J Clin Oncol 7: 194-199. 
Carr MJ, McCormack GP, Mutton KJ, Crowley B. 2006. Unique BK virus non-coding control region (NCCR) variants in hematopoietic stem cell transplant recipients with and without haemorrhagic cystitis. J Med Virol 78: 485-493.

DeVries CR, Freiha FS. 1990. Haemorrhagic cystitis: a review. J Urol 143: 1-9.

Drachenberg CB, Hirsch HH, Papadimitriou JC, Gosert R, Wali RK, Munivenkatappa R, Nogueira J, Cangro CB, Haririan A, Mendley S, Ramos E. 2007. Polyomavirus BK versus JC replication and nephropathy in renal transplant recipients: a prospective evaluation. Transplantation 84: 323-330.

Dropulic LK, Jones RJ. 2008. Polyomavirus BK infection in blood and marrow transplant recipients.Bone Marrow Transplant 41: 11-18.

Erard V, Kim HW, Corey L, Limaye A, Huang ML, Myerson D, Davis C, Boeckh M. 2005. BK DNA viral load in plasma: evidence for an association with haemorrhagic cystitis in allogeneic hematopoietic cell transplant recipients. Blood 106: 1130-1132.

Ferrante P, Delbue S, Pagani E, Mancuso R, Marzocchetti A, Borghi E, Maserati R, Bestetti A, Cinque P. 2003. Analysis of JC virus genotype distribution and transcriptional control region rearrangements in human immunodeficiency virus-positive progressive multifocal leukoencephalopathy patients with and without highly active antiretroviral treatment. J Neurovirol 1: $42-46$.

Fioriti D, Degener AM, Mischitelli M, Videtta M, Arancio A, Sica S, Sora F, Pietropaolo V. 2005. $\mathrm{BKV}$ infection and haemorrhagic cystitis after allogeneic bone marrow transplant. Int $\mathrm{J}$ Immunopathol Pharmacol 18: 309-316. 
Frisque RJ, Bream GL, Cannella MT. 1984. Human polyomavirus JC virus genome. J Virol 51: 458-469.

Giraud G, Bogdanovic G, Priftakis P, Remberger M, Svahn BM, Barkholt L, Ringden O, Winiarski J, Ljungman P, Dalianis T. 2006. The incidence of haemorrhagic cystitis and BK-viruria in allogeneic hematopoietic stem cell recipients according to intensity of the conditioning regimen. Haematologica 91: 401-404.

Giraud G, Priftakis P, Bogdanovic G, Remberger M, Dubrulle M, Hau A, Gutmark R, Mattson J, Svahn BM, Ringden O, Winiarski J, Ljungman P, Dalianis T. 2008. BK-viruria and haemorrhagic cystitis are more frequent in allogeneic haematopoietic stem cell transplant patients receiving full conditioning and unrelated-HLA-mismatched grafts. Bone Marrow Transplant 41: 737-742.

Gosert R, Rinaldo CH, Funk GA, Egli A, Ramos E, Drachenberg CB, Hirsch HH. 2008. Polyomavirus BK with rearranged noncoding control region emerge in vivo in renal transplant patients and increase viral replication and cytopathology. J Exp Med. 2008 205:841-852.

Ikegaya H, Saukko PJ, Tertti R, Metsärinne KP, Carr MJ, Crowley B, Sakurada K, Zheng HY, Kitamura T, Yogo Y. 2006. Identification of a genomic subgroup of BK polyomavirus spread in European populations. J Gen Virol 87: 3201-3208.

Imperiale MJ. 2000. The human polyomaviruses, BKV and JCV: molecular pathogenesis of acute disease and potential role in cancer. Virology 267: 1-7. 
Imperiale MJ. 2001. The Human Polyomavirus: an overview. In: Khalili K, Stoner G.L, editors. Human Polyomaviruses: molecular and clinical perspectives. New York: Wiley-Liss, A John Wiley \& sons, Inc. p 53-71.

Jin L, Gibson PE, Booth JC, Clewley JP. 1993. Genomic typing of BK virus in clinical specimens by direct sequencing of polymerase chain reaction products. J Med Virol 41: 11-17.

Jin L, Pietropaolo V, Booth JC, Ward KH, Brown DW. 1995. Prevalence and distribution of BK virus subtypes in healthy people and immunocompromised patients detected by PCR-restriction enzyme analysis. Clin Diagn Virol 3: 285-295.

Jobe DV, Friedlaender JS, Mgone CS, Agostini HT, Koki G, Yanagihara R, Ng TCN, Chima SC, Ryschkewitsch CF, Stoner GL. 2001. New JC virus (JCV) genotypes from Papua New Guinea and Micronesia (type 8 and type 2E) and evolutionary analysis of 32 complete JCV genomes. Arch Virol 146: 2097-2113.

Khalili K, Gordon J, White MK. 2006. The polyomavirus, JCV and its involvement in human disease. Adv Exp Med Biol 577: 274-287.

Kim HS, Henson JW, Frisque RJ. 2001. Transcription and replication in the Human Polyomaviruses. In: Khalili K, Stoner G.L, editors. Human Polyomaviruses: molecular and clinical perspectives. New York: Wiley-Liss, A John Wiley \& sons, Inc. p 73-126.

Kmieciak D, Debicki S, Trzeciak WH. 2008. Occurrence rate and genotype distribution of the JC virus (JCV) in a sample from the Polish population. J Med Virol 80: 1079-1083. 
Knowles WA. 2006. Discovery and epidemiology of the human polyomaviruses BK virus (BKV) and JC virus (JCV). Adv Exp Med Biol 577: 19-45.

Krumbholz A, Wutzler P, Zell R. 2008. The non-coding region of BK subtype II viruses. Virus Genes 36: 27-29.

Leung AY, Suen CK, Lie AK, Liang RH, Yuen KY, Kwong YL. 2001. Quantification of polyoma BK viruria in haemorrhagic cystitis complicating bone marrow transplantation. Blood 98: 19711978.

Leung AY, Suen CK, Lie AK, Liang RH, Yuen KY, Kwong YL. 2001. Quantification of polyoma BK viruria in haemorrhagic cystitis complicating bone marrow transplantation. Blood 98: 19711978.

Leung AY, Yuen KY, Kwong YL. 2005. Polyoma BK virus and haemorrhagic cystitis in hematopoietic stem cell transplantation: a changing paradigm. Bone Marrow Transplant 36: 929937.

Mischitelli M, Fioriti D, Anzivino E, Bellizzi A, Ferretti G, Gussman N, Mitterhofer AP, Tinti F, Barile M, Dal Maso M, Chiarini F, Pietropaolo V. 2007. BKV QPCR detection and infection monitoring in renal transplant recipients. New Microbiol 30: 271-274.

Mischitelli M, Fioriti D, Videtta M, Degener AM, Antinori A, Cinque P, Giordano A, Pietropaolo V. 2005. Investigation on the role of cell transcriptional factor Sp1 and HIV-1 TAT protein in PML onset or development. J Cell Physiol 204: 913-918. 
Moens U, Van Ghelue M. 2005. Polymorphism in the genome of non-passaged human polyomavirus BK: implications for cell tropism and the pathological role of the virus. Virology 20: 209-231.

Pagani E, Delbue S, Mancuso R, Borghi E, Tarantini L, Ferrante P. 2003. Molecular analysis of JC virus genotypes circulating among the Italian healthy population. J Neurovirol 9: 559-566.

Pietropaolo V, Di Taranto C, Degener AM, Jin L, Sinibaldi L, Baiocchini A, Melis M, Orsi N. 1998. Transplacental trasmission of human polyomavirus BK. J Med Virol 56: 372-376.

Pietropaolo V, Videtta M, Fioriti D, Mischitelli M, Arancio A, Orsi N, Degener AM 2003. Rearrangement patterns of JC virus noncoding control region from different biological samples. J Neurovirol 9: 603-611.

Przepiorka D, Jaeckle KA, Birdwell RR, Fuller GN, Kumar AJ, Huh YO, McCutcheon I. 1997. Successful treatment of progressive multifocal leukoencephalopathy with lowdose interleukin-2. Bone Marrow Transplant 20: 983-987.

Rabenau HF, Preiser W, Franck S, Schwerdtfeger S, Doerr HW. 2002. Polyomavirus viruria in bone marrow transplant recipients: lack of correlation with clinical symptoms. Infection 30: 91-93. Reploeg MD, Storch GA, Clifford DB. 2001. BK virus: a clinical review. Clin Infect Dis 33: 191202.

Rossi A, Delbue S, Mazziotti R, Valli M, Borghi E, Mancuso R, Calvo MG, Ferrante P. 2007. Presence, quantitation and characterization of JC virus in the urine of Italian immunocompetent subjects. J Med Virol 79:408-412. 
Russel SJ, Vowels MR, Vale T. 1994. Haemorrhagic cystitis in pediatric bone marrow transplant patients: an association with infective agents, GVHD and prior cyclophosphamide. Bone Marrow Transplant 13: 533-539.

Santos GW, Tutschka PJ, Brookmeyer R, Saral R, Beschorner WE, Bias WB, Braine HG, Burns WH, Elfenbein GJ, Kaizer H, et al. 1983. Marrow transplantation for acute non-lymphocytic leukemia after treatment with busulfan and cyclophosphamide. N Engl J Med 309: 1347-1353.

Sencer SF, Haake RJ, Weisdorf DJ. 1993. Haemorrhagic cystitis after bone marrow transplantation. Transplantation 56: 875-879.

Sharma PM, Gupta G, Vats A, Shapiro R, Randhawa PS. 2007. Polyomavirus BK non-coding control region rearrangements in health and disease. J Med Virol 79: 1199-1207.

Stoner GL, Hübner R. 2001. The Human Polyomaviruses: past, present, and future. In: Khalili K, Stoner G.L, editors. Human Polyomaviruses: molecular and clinical perspectives. New York: Wiley-Liss, A John Wiley \& sons, Inc. p 611-663.

Stoner GL, Jobes DV, Cobo MF, Agostini HT, Chima SC, Ryschkewitsch CF. 2000. JC virus as marker of human migration to the Americas. Microbes Infect 2: 1905-1911.

Sundsfjord A, Spein AR, Lucth E, Flaegstad T, Seternes OM, Traavick T. 1994. Detection of BK virus DNA in nasopharyngeal aspirates from children with respiratory infections but not in saliva from immunodeficient and immunocompetent adult patients. J Clin Microbiol 32: 1390-1394. 
Vaz B, Cinque P, Pickhardt M, Weber T. 2000. Analysis of the transcriptional control region in multifocal leukoencephalopathy. J Neurovirol 6: 398-409.

Xu LP, Zhang HY, Huang XJ, Liu KY, Liu DH, Han W, Chen H, Chen YH, Gao ZY, Zhang YC, Lu DP. 2007. Haemorrhagic cystitis following hematopoietic stem cell transplantation: incidence, risk factors and association with CMV reactivation and graft-versus-host disease. Chin Med J 5: 1666-1671.

Yang CC, Hurd DD, Douglas Case L, Assimos DG. 1994. Haemorrhagic cystitis in bone marrow transplantation. Urology 44: 322-328.

Yasuda Y, Yabe H, Inoue H, Shimizu T, Yabe M, Yogo Y, Kato S. 2008. Progressive multifocal leukoencephalopathy after allogeneic bone marrow transplantation for Wiskott-Aldrich syndrome. Pediatr Int 50: 238-240.

Zambrano A, Kalantari M, Simoneau A, Jensen JL, Villarreal LP. 2002. Detection of human polyomaviruses and papillomaviruses in prostatic tissue reveals the prostate as a habitat for multiple viral infections. Prostate 53: 263-276.

Zheng HY, Nishimoto Y, Chen Q, Hasegawa M, Zhong S, Ikegaya H, Ohno N, Sugimoto C, Takasaka T, Kitamura T, Yogo Y. 2007. Relationships between BK virus lineages and human populations. Microbes Infect 9: 204-213.

Zhong S, Zheng HY, Suzuki M, Chen Q, Ikegaya H, Aoki N, Usuku S, Kobayashi N, Nukuzuma S, Yasuda Y, Kuniyoshi N, Yogo Y, Kitamura T. 2007. Age-related urinary excretion of BK polyomavirus by nonimmunocompromised individuals. J Clin Microbiol 45: 193-198. 
Table 1: Clinical data of BMT patients

\begin{tabular}{|c|c|c|c|c|c|c|c|}
\hline $\mathbf{P z}$ & Clinical history & BMT & HC onset & $\begin{array}{c}\text { Polyomavirus } \\
\text { infection }\end{array}$ & $\begin{array}{l}\text { Other viral } \\
\text { infections* }\end{array}$ & Other complications & Outcome \\
\hline F1 & AML & MUD 03-18-05 & 60 days after BMT & BKV & $\mathrm{AdV}, \mathrm{CMV}, \mathrm{EBV}$ & LPD-EBV related & dead \\
\hline F2 & NHL & MUD March 2008 & 10 days after BMT & $\mathrm{BKV}$ & none & $\begin{array}{c}\text { Numerous bacterial } \\
\text { infections }\end{array}$ & dead \\
\hline F3 & AML & MUD 05-05-07 & 20 days after BMT & BKV & EBV & I & dead \\
\hline M4 & ALL T cells & BMT from relative 05-09-07 & 60 days after BMT & $\mathrm{BKV}$ & CMV & Acute GVHD & dead \\
\hline M5 & ALL & MUD 05-10-05 & 30 days after BMT & $\underline{J C V}$ & EBV & 1 & dead \\
\hline F6 & ALL PH+ & MUD 11-21-06 & 30 days after BMT & $\mathrm{BKV}, \underline{J C V}$ & CMV, EBV & / & $\begin{array}{c}\text { remission: } \\
\text { dasatinib administration; DLI }\end{array}$ \\
\hline M7 & M3-AML & MUD 02-16-07 & 20 days after BMT & $\mathrm{BKV}, \underline{\boldsymbol{J C V}}$ & CMV, EBV & / & M3-AML recidivant \\
\hline
\end{tabular}

Legend: ALL PH+ = Acute Lymphoblastic Leukemia Chromosome Philadelphia Positive; M3-AML = M3 Acute Myelocytic Leukemia; AML = Acute Myelocytic Leukemia; NHL = Non Hodgkin's Lymphoma; MUD = Match Unrelated Donors; LPD = LinfoProliferative Disorders; GVHD = Graft Versus Host Disease; DLI: Donor Leukocyte Infusions.

*: AdV, EBV and CMV infections were monitored according to BMT guidelines and they were recruited from patient's medical case sheets. 


\section{Table 2: Patients treatments}

\begin{tabular}{|c|c|c|c|c|}
\hline Pz & $\begin{array}{c}\text { GVHD } \\
\text { Prophylaxis }\end{array}$ & Conditioning regimen & Antiviral therapy & Other therapies \\
\hline F1 & MTX, CYSP & Bu, Cy, ATG & Rib, Gancyclovir, Foscarnet, Rituximab & / \\
\hline F2 & MTX, CYSP & TBI, Cy, Adriamycin & Rib & Cid, Rib \\
\hline F3 & MTX, CYSP & Bu, Cy, ATG & Gancyclovir, & Corticosteroids, MMF, Thalidomide, Alemtuzumab Infliximab \\
\hline M4 & MTX, CYSP & $\mathrm{Bu}, \mathrm{Cy}, \mathrm{AraC}$ & Cid, Rib & / \\
\hline M5 & MTX, CYSP & $\mathrm{Bu}, \mathrm{Cy}, \mathrm{AraC}$ & Antibiotic therapy, Probenecid, Risperidone \\
\hline F6 & MTX, CYSP & TBI, Cy, ATG & Cid, Rib, Gancyclovir, Rituximab & Antibiotic therapy, Probenecid \\
\hline M7 & MTX, CYSP & $\mathrm{Bu}, \mathrm{Cy}, \mathrm{ATG}$ & Cid, Rib & \\
\hline
\end{tabular}

Legend: MTX: Methotrexate; CYSP: Cyclosporin; TBI = Total Body Irradiation; $\mathrm{Cy}=$ Cyclophosphamide; Bu = Busulfan; ATG = Antihuman Thymocyte Globulin; AraC $=$ Cytarabin; Cid= Cidofovir; Rib= Ribavirin; MMF: Mycophenolate Mofetil 
Table 3: Results of quantitative and qualitative assays for BK and JC viruses.

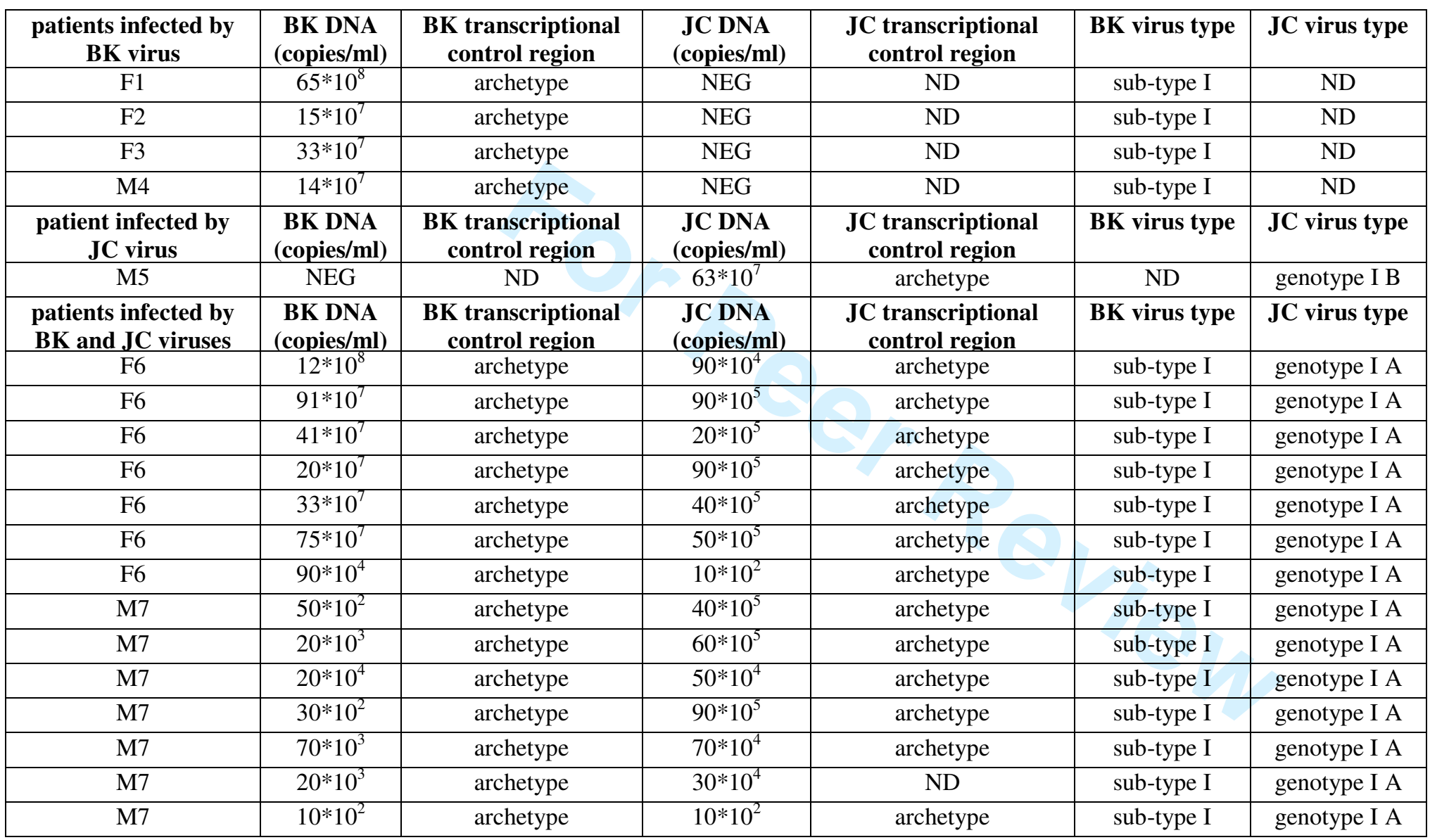

Legend: $\mathrm{NEG}=$ negative, $\mathrm{ND}=$ not determined $\mathrm{F}=$ female $\mathrm{M}=$ male 